\title{
Psychological Security of Two Generations in Latvia
}

\author{
Gershons Breslavs* \\ Baltic Psychology and Management University College \\ 65 Bruninieku Str., Riga, LV 1011, Latvia
}

Received 17.09.2014, received in revised form 14.10.2014, accepted 22.11.2014

The breakup of Soviet Union and transition from "well-developed socialism" to market economy led to the changes in the attitudes and the lifestyle of the people. Have these changes made human communication safer? The most important sociopsychological condition for such security is the absence of interpersonal and intergroup aggression, as well as the hatred that tends to provoke the explosions of such aggression. Has this condition changed in the life of generation educated in the market-economy society? Are these changes accompanied by the changes in mental variables that prevent the explosions of aggression, particularly in changes of experience of love and satisfaction with life? The aim of our study is the comparison of aggression, hate, love, and satisfaction with life that characterized the generation educated in Soviet Union (43-50 years old) and the same features of the younger generation (18-25 years old), educated after the breakup of Soviet Union in Latvia. Hypothesis on the existence of intergenerational distinctions on these variables was confirmed partly: distinctions were revealed in the inclination to aggression, satisfaction with life, and love passion. All these variables are higher in young generation, which could be explained more by age-specific features than by more general changes in the social-economic and social-political circumstances.

Keywords: psychological security, aggression, hate, subjective well-being, satisfaction with life, love, hostility, intergenerational distinctions.

Research area: psychology.

After the breakup of Soviet Union, it became evident that the stereotype of Soviet people's internationalism, disseminated in the literature and mass media of the USSR, was far from reality. In a number of former Soviet republics military conflicts exploded between different ethnic, religious and tribal communities (Kara bah, Prydnestrovje, Abkhazia, Ossetia, Chechnya, Ingushetia, Dagestan). Situation in these regions, as in some others in the former Soviet territory, is still far from secure till today. The issues of security include a number of political, military, economic, and social-psychological aspects. Our study is directed at the last aspect only. It is aimed at evaluating the readiness and desire to harm other persons and groups, and exploring available resources for the minimization of these tendences.

\section{Insecurity of modern world and aggression}

Contradictions of the Globalization epoch include incredible extent of humanistic values

(C) Siberian Federal University. All rights reserved

* Corresponding author E-mail address: g_bresl@1atnet.lv 
(human rights, democracy, and equity) on the one hand, and the escalation of interethnic, intertribal, intergroup and international conflicts in the world, on the other hand. Most popular reasons of such conflicts are the struggle against social discrimination and the struggle for realization of in-group values and aims. In the Western Europe and North America these conflicts were resolved more or less in a peaceful and non-violent manner but it is not the case in the other regions of the world. At the same time, frictions and tensions in the relationships of different groups in relatively successful countries have emerged that arouse antisocial activities of mentally unbalanced persons. Furthermore, in all European countries relationships between different groups have been aggravated by the past wars, violence and injustices. These tensions rooted in the past constantly threaten to escalate minor misunderstandings into full-blown, serious conflicts.

If people perceive neighbor nation or religious out-group as enemies and have intentions to resolve conflicts in a violent manner until the final victory, it is not difficult to find reason for the next violent action. In every country is possible to find many collective injuries, or instances of violence committed against one's group in the past. For example, many ethnic groups in the post-Soviet space condemn Russians as representatives of the majority for Stalin's regime atrocities. In the same time, it is clear that the greatest number of Stalin's victims were Russians themselves, but they didn't suffer from massive deportations of 1944 that the Kalmyk, the Chechen, the Crimea's Tatars, the German at Volga (1941), Ingush and other ethnic groups were subject to. To this day, these ethnic groups perceive the Russians as perpetrators of this suffering on their people. Huge migrations that happened after the breakup of the Soviet Union didn't substantially soften these intergroup antagonisms. Political migrants from former Soviet Asian republics, mainly ethnic Russians, arouse the same hostility to Middle Asian ethnic people as their coming to Russia as guest workers. This hostility in the turn may lead to the acts of aggression.

In contemporary psychology most popular classification of aggression types is the differentiation of proactive (initiative) and reactive aggression (Dodge, 1991). The majority of cultures consider proactive aggression outside of war, sport or busness competition as negative phenomenon. On the other hand, reactive aggression is often viewed as positive, and interpreted as justice reinstatement (Nisbett $\&$ Cohen, 1996). In all countries we can find legal or informal rules of social exchange, with rewards for socially approved actions and punishments for transgressions. In the meantime, many agressors consider their own attacks as a revenge only - as reaction to unjust actions of target person or group's previous transgressions (Michener, 2012). It means that in the people's mind it isn't easy to differentiate proactive and reactive aggression toward an out-group because it is easy to find some transgressions for the target group's acitivities in the past.

Recently in psychology was proposed the concept of vicarious retribution. It means aggression directed to person or group that didn't do something wrong to agent of aggression but harmed to ingroup in the past (Lickel, Miller, Stenstrom, Denson \& Schmader, 2006). For example, Palestinian terrorists consider that their terroristic actions are a reaction only on Jewish aggression and occupation of their lands in 1948. Arab leaders told them that it is temporary expatriation and they will come back soon as owners of all lands. The same rhetoric in the camps of Paslestinian refugees continues until today. Similarly, the victims of these terrorists are becoming regular residents, and we can analyse these facts in the framework of 
displaced aggression. In the environment marked by poverty and desperation, as in the camps of Paslestinian refugees, the probability of such aggresion becomes higher (Marcus-Newhall, Pedersen, Carlson, \& Miller, 2000). This violence from Palestinians in Gaza can be defined as hate crimes and presuppose hatred and hostility to a target group's representatives for their social belonging only (Cheng, Ickes, Kenworthy, 2013; Lawrence, 1999).

\section{The Sources of Hate}

In all totalitarian countries (and in the past in all countries) we can find the long-time social discrimination of different social groups that leads to their radicalization, strongly related to the unemployment of youngsters. As we can see today in many Islamic countries, the young people were becoming the propelling force of political changes in these countries. The majority of terrorists are very young . Researchers of terrorism believe that often very talanted youngsters who had been discriminated against solely because of their social background became involved in these terrorist groups (McCauley \& Moskalenko, 2011).

For example, Vladimir Ulyanov-Lenin was rejected from Kazan University for his older brother Alexander's participation in the attempt on the life of Tsar Alexander II. Vladimir was not very close with the brother but after this rejection and execution of his brother he became dissident to Caesarism (monarchy), and next years of his life showed step-by-step process of his radicalization and development of hatred towards all major social groups of Russia. It is difficult to understand brutal repressions of workers' outcries and peasants' rebellions after the conquest of power in 1917 by the Bolshevik's party without hate, because in Lenin's political theory based on Marx' ideas worker class and partly peasants were the basis of new communist society.
Many atrocities, including massacres and collective violence, outside the framework of war, is impossible explain without the concept of hate (Sternberg \& Sternberg, 2008). Sometimes hate crimes could be explained by vicarious retribution based on hate. Recent atrocious killing of British soldier-drummer in London by local Islamists could be a good example of such vicarious retribution. The killer exclaimed, brandishing a bloody hatchet, that this murder was the revenge to the British army for the previous killing of our (Muslim) women in Afghanistan.

In the framework of European culture confession of own hate to out-group looks unacceptable and is commonly substituted by negative stereotypes about this group (Breslavs, Ābele, Derjabo, Pišinska \& Roze, 2008) or by resentment and contempt. The target of hate is perceived as powerful and irrationally influential (Breslav, 2011). Often to the target are attributed reasons of all societal problems and natural disasters, economic crises, riots, and military conflicts. Anti-Semites could find intrigues of the Jewish mafia in all social conflicts and problems, from unemployment and high taxes to floods and infestations. It would be useful to differentiate cultivated hate, inside particular social norms and standards (Bar-Tal, 2002), for example, the hate towards the Jews in the camps of Palestinian refugees, and hate outside such norms that has no rational basis in real life. But both types of hate could arouse very tragic consequences through brutal violence that we can see in regular military conflicts and explosions of violence in the Middle East. Israel's data collected in the time of military conflict with the Lebanon's Hezbollah at 2006 and after that showed that hate only strongly predicted political intolerance of Israel residents especially in the time of war and among unsophisticated participants (Halperin, Canetti-Nisim, HirschHoefler, 2009). 
Does this mean that individuals who are the targets of hate will immediately become the objects of aggression and violence? It is not certain, but the probability of such outcome is higher than the probability of violence towards other people. Particularly, we know that the target of hate arouses more strong and frequent anger reactions of haters (Bar-Tal, 2002). Ruminations about resentments are directly correlated with inclination to hostility and aggression (Anestis, M., Anestis, J., Selby, \& Joiner, 2009); also hostility and aggression are stable interconnected (Burt, Mikolajewski \& Larson, 2009).

Ambiguity of the link between hate and aggression in our data is in part due to the two-element structure of hate - passive and active (Breslav, 2011). While the first element is manifested by escaping and distancing only, the second is manifested by condemnation and trying to harm the target of hate including physical violence. If the active element of hate is dominant, we could predict aggression with high probability, but not in the case of passive hate priority in the structure of hate. In the same time our data shows that in comparison of adolescents (16-18 years old) to adults (26-28 and 36-38) element of active hate significantly decreases in both adult groups, but there is no differences in passive hate (Breslavs, 2009). In this study no gender differences were found in both hate elements, but some recent data show higher passive hate for Latvian-speaking men (Kristapsone, 2014).

\section{Psychological counterbalances of aggression and hate}

Data on aggression and hate in the world can shape the concept of inevitability of endogen violence in society and, accordingly, on a necessity of state violence and the increase of police control for the limitation of aggression. But can we find non-violent psychological means how to solve this task? The number of such tools in our century is substantial: productive ways of conflicts resolution, development of cooperative skills, empathy and forgiveness development, improving optimistic attitudes, increase of satisfaction with life, and especially development of love. We will discuss last two ways, due to the significant progress that has been made in the assessment of these variables in psychology.

According to many studies variable satisfaction with life overlapped with such popular in psychology variable as subjective well-being (Diener, 1984; Diener, E. \& Diener, M. 1995; Headey \& Wearing, 1991). Particularly, Diener considers own measure of satisfaction with life SWLS at the same time as the measure of subjective well-being (Diener, 2006; Pavot, \& Diener, 1993;). The APA dictionary defines subjective well-being as "a judgement that people make about the overall quality of their lives by summing emotional ups and downs to determine how well their actual life circumstances match their wishes or expectations concerning how they should or might feel" (APA, 2007, p.904).

If one replaces "judgment" by a more general concept of "experience" or "awareness of life's quality" it would fit the subject matter of our studies. In this definition are represented two main components of satisfaction - emotional (balance of positive and negative emotions) and cognitive (alignment with expectations or aspirations). It appears that satisfaction with life could be interpreted as a core of subjective wellbeing. In turn, subjective well-being could be considered as an indicator of: 1) quality of life; 2) social-psychological adaptation; 3) mental health; 4) happiness (Breslavs, 2007).

People who feel enough happiness revealed positive link of life satisfaction with frequency and interpretation of positive events (.41 and .27, accordingly), but the lack of link with frequency and interpretation of negative events (.00 and -.02). People who feel unhappy revealed positive 
link of life satisfaction with frequency and interpretation of positive events (.25 and .28, accordingly) but the negative link with frequency and interpretation of negative events (-.32 and -.50) (Oishi, Diener, Choi, Kim-Prieto \& Choi, 2007). These data could be interpreted that persons who can successfully cope with negative events and emotions feel happier. Manifestions of hate and aggression are a prime example of such negative events, suggesting a negative correlation between life satisfaction, on the one hand, and hate $\&$ aggression on the other hand.

Despite the centuries-long history of religious beliefs and feelings (Hood, Spilka, Hunsberger \& Gorsuch, 1996; Wulff, 1997), psychologists can't claim a full understanding of love to God (Fromm, 1956), although its role in the overcoming stress and existential fear was studied in detail (Pargament, 1997). In the meantime, more realistic forms of love, such as partnership love, became the subject matter of serious scientific studies in the last 40 years (Sternberg \& Barnes, 1988; Sternberg \& Weis, 2006; Breslav, 2014). At the moment all aspects of partnership love have more or less been studied including the role of love in the change of partners' attitudes according to lovers' expectations (Murray, Holmes, Griffin, 1996).

Yet Spinoza proposed in the third part of his famous Ethica in the comments to theorem 13: consider love and hate as dichotomy (fully alternative) sentiments: “...Love is nothing else but pleasure accompanied by the idea of an external cause. Hate is nothing else but pain accompanied by the idea of an external cause. We further see that he who loves necessarily endeavors to have, and to keep present to him, the object of his love; while he who hates endeavors to remove and destroy the object of his hatred."

Such statement presupposes direct opposition of these sentiments, although Spinoza told about different external reasons in the cases of love and hate. This understanding of hate was perceived by contemporary researchers as basic.

Recently, Rempel and Burris formulated the comprehensive theory of love and hate (Rempel, \& Burris, 2005). "We understand love to be a motivational state in which the goal is to preserve and promote the well-being of the valued object. (Rempel, \& Burris, 2005, p.299). In the same time...hate is a motive associated with the goal of destroying or diminishing the object's wellbeing" (p.300). At the same time they consider that "there are multiple forms of the love and hate motives, with distinctions among their associated goals paralleling those of instrumental (or proximal) goals and ultimate goals" (Rempel \& Burris, 2005, p.301). It means that "loving" or "hating" behaviors have multiple causes. Every emotion, according this theory, could elicit love or hate when two conditions would be satisfied. "First, the would-be loved or hated other must be perceived to be the cause of one's emotional experience. Second, as a consequence of this attribution of responsibility, the other must be either valued or devalued-in effect, deemed worthy or unworthy" (p.302). Surely love and hate can't be considered as motives only, but there's no doubt that these sentiments are produced by a number of such thoughts and emotions, and participate in the emergence of severity of our motives and aims, whether prosocial, egocentric or antisocial (Breslav, 2011).

Other researchers consider hate as a negative identification of a person contrary to love as a positive identification (Royzman, McCauley, \& Rozin, 2005, p. 5). The idea looks very attractive because we want not only remove the hated rather far from our life space, but mere idea of our similarity with the hated also horrifies us. People want to be opposite in all their performances and traits with the hated. If the person emphasizes own humanistic values and orientation he/she will try to persuade him/herself that the hated 
have anti-humanistic values and orientations. Likewise, xenophobic attitudes presuppose such opposition to the hated persons.

Empirical data show that anger that can be the consequence of hate as stimuli for aggression can predict interpersonal aggression, but it happens independently from love (Ellis \& Malamuth, 2000). At the same time, the decrease of anger and distress as the increase of love may also predict the satisfaction with partnership. It gives evidence that love can successfully coexist with negative emotions including anger and aggression (Ellis, Malamuth, 2000). Our data show that an existence of love doesn't exclude an inclination to hate. Between these sentiments were found non-significant but positive links in all three age groups (16-18, 26-28, 36-38) (Breslavs, 2009).

Similarly, the subject matters of hate and love don't coincide. Ambivalent attitude of infant to mother's breast (simultaneous performance of love and hate) proposed by Melanie Klein in 1928 (Klein, 1986), was not accepted in London's school of psychoanalysis despite her leadership in this area. In the same time it is difficult to reject potential for such emergence for preschool child toward mainly absent and drinking father or mother. Similar ambivalence is easy to find at a particular stage of marriage's breakup (Knapp, \& Vangelisti, 1992). But outside of these very specific situations, the coincidence of these subject matters should be considered as a deviation. It is very understandable because subject matter of romantic love is always personified, while the object of hate may be not only a person, but a large group, acquaintance with which could be very causal and superficial (Breslav, 2011).

\section{Cultural-historical context of the study}

Transition from Soviet to post-Soviet society signified the change of ideological priorities. Values of equity, centralized standards and subordination of individual to the collective and state of Soviet time became quickly transformed in the public space into Christian values, liberalism, and free market economy. Despite a definite trend in this direction, according to sociological view, "dominant basic values of Russian residents' majority are traditionalistic, adaptive and nonoriented on achievements" (Gudkov et al., 2008). The negative attitudes toward rich people and to wealth are understandable, taking into account the speed of privatization of factories and productions, and illegal nature of acquisition of immense wealth during that early period.

In the same time, children of this Soviettime generation, educated at the stage of market economy, perceived these new values as an objective reality. Surely, the new generation also perceived dissatisfaction of their parents with the status quo, but they had not alternatives to compare and they could not reasonably share with parents' ground for negative estimation of new state with market economy and new priorities. This difference created a stable stereotype on different psychological image of people educated in Soviet time and young generation educated in post-Soviet stage of democratic institutions' development. To the Soviet generation essentially was ascribed inclination to autoritarian ways of management, preference of vertical hierarchy, uncritical conformism, intolerance to minority outgroups, distrust for democratic institutions and lack of initiative in community's life (Allik, \& Realo, 1996; Draguns, 1999; Gulens, 1995; Levada, 2005). In turn, young post-Soviet people were considered as free from automatic subordination, more tolerant to outgroups, more prone to initiative in social life, more open to new experience, and having more trust towards democratic institutions and human rights.

However, the issue of two generations' differences is not so clear, because primary socialization is processed in family and upbringing 
leads to reproduction of the same attitudes. Role of parents is difficult to overestimate, since stereotypes shared by adolescents come mainly not from peers' prejudices (Ritchey, Fishbein, 2001). The Internet can compete and leave behind family by amount of information but the ocean of information can be organized in the person's knowledge system on the basis of definite priorities (attitudes and moral standards), and these priorities are assimilated in real social interaction only.

In the same time, these priorities and attitudes are mediated not only by social belonging of their parents (language and norms of friends, colleagues, neighbors) but by social attitudes and norms of societal majority too (Breslav, 1994). For example, we can presuppose that ethnic Russians living in Latvia and Lithuania will be influenced, accordingly, by Latvian and Lithuanian ethnic cultures. But this influence will be not so big for Latvian Russians then for Lithuanian Russians because Russian-speaking people proportion in 1990 was near $50 \%$ and in the big cities higher than $60 \%$ but in Lithuania this proportion was below $15-20 \%$ that means the lack of big Russian-speaking community in the majority of cities and necessity to assimilate local language and cultural traditions. In Latvian cities Russian-speaking people are living in own self-sufficient community and this big ethnic segregation results in interethnic tensions and in social discrimination of Russian-speaking residents (Breslavs, Ābele, Derjabo, Pišinska \& Roze, 2008).

\section{Design of the study}

How many people in Latvia and Russia are inclined to hate and aggression? To what extent do they have intentions and feelings that can restrict tendencies to violence and hate crimes? How much these attitudes and feelings depend on age, culture and differences in environment? The content of our research consists of the answers to these questions.

Comparison of two generations in postSoviet space - the generation educated in the Soviet time, and the generation educated after the breakup of Soviet Union -- will highlight important tendencies in conservation or change of hate and readiness to aggression. This comparison will highlight the role of cultural context and factors of globalization and individualization. Social-economic factors in the turn could be balanced by age factor that can predict higher level of aggression in young generation.

It was expected to discover higher level of hate in culture where this sentiment is perceived as normal and acceptable in comparison with the culture where hate is more or less considered taboo. For example, in Latvian culture hate has a status of indecent sentiment and most commonly unambiguously was rejected as own attitude to other persons (Breslavs, et al., 2008). The same suppression of hate and hostility is common for residents in North America and Western Europe in majority of everyday relationships.

According to Berkowitz's theory of aggression, higher level of aggression will be expected in poor disadvantaged environment where level of discomfort is higher than in middle and upper class families (Berkowitz, 1993). According to interpersonal theory, aggression could be considered as an outcome of social isolation and social discrimination (Leary, Twenge, \& Quinlivan, 2006). While for negative factors of aggression can be considered stable partnership and level of education that, in the turn, can be a factor of social connection improvement. Satisfaction with life could be considered as negative factor of aggression and hate because just frustration of basic needs was described as a main reason and basis of aggression (Dollard, Doob, Miller, Mowrer \& Sears, 1939). Satisfaction with life, in the turn, 
is linked with love (Kim \& Hatfield, 2004), that could be considered as a definite counterbalance and a defense from aggression and hate.

Our aim was the study of hate, aggression, love and satisfaction with life of two generation of Russian residents (Dagestan, Ingushetia, Kabardino-Balkaria, Krasnoyarsk, and Moscow) and two generations of Latvian residents (Latvianand Russian-speaking). Taking into account technical problems in collecting data in Russia this analysis focused on analysis of Latvian data only.

\section{Methods}

According to the aim were selected appropriate measures of main variables. As an aggression measure was selected popular Buss-Perry scale, which was adapted in Russia (Enikolopov, Cibulsky, 2007). Original scale includes four factors and appropriate subscales physical aggression $(\alpha=.85)$, verbal aggression $(\alpha=.72)$, hostility $(\alpha=.77)$, and anger $(\alpha=.83)$. It shows high retest reliability .80 when retesting more than after 9 weeks (Buss \& Perry, 1992). In processing of Russian version results of factor analysis showed the elimination of verbal aggression factor. Our work on adaptation of this measure using component factor analysis with Julia Tjumeneva at 2005-2006 showed the same tendency - the items on verbal aggression factor were split into three other factors. As result Russian version includes three factors only and accordingly three subscales: physical aggression, hostility, and anger.

Selection opportunities for hate assessment are more limited because research interest emerged in the beginning of 21 century only (Breslav, 2011; Burris \& Rempel, 2008; Sternberg, 2003; Sternberg, 2005; Sternberg \& Sternberg, 2008). At the moment two measures only attempt to assess hate (Breslav, 2004; Breslavs \& Tyumeneva, 2008, b; Weis, 2006). First measure can be described as direct assessment measure because participants estimate own feelings toward somebody (individual or group's target). Karen Weis (Sternberg) measure consists of 30 items - statements and estimate reflective feelings to proposed scenario where one personage (agent) takes moral transgression dangerous for life of the other person (victim). These items include different emotions and attitudes aroused by the agent of this scenario. In this measure isn't able to really differentiate long-term sentiment hate from short-term emotions such as anger, resentment or disgust.

We started to develop a new measure of hate on the basis of Sternberg's triangular model of hate (Breslav, 2004; Sternberg, 2003). But in the process of factor analysis of collected data with the first version of 45-item measure of hate was revealed splitting of second subscale by Sternberg (fear and anger) to two other subscales. It led to new two-factor model of hate (active and passive) and the creation of new 18-item measure with two subscales (Breslav, 2011; Breslavs \& Tyumeneva, 2008, b).

For the assessment of subjective well-being and satisfaction with life was selected SWLS (Satisfaction with Life Scale), that, despite 5-item 7-points scale, was characterized with high validity and reliability (Diener, Emmons, Larsen \& Griffin, 1985). The SWLS measures global satisfaction with life that represents an integration of severity of components where some of them are not balanced with others. Person can be satisfied with own family life but not satisfied with economic situation and own health, or can be satisfied with own health, but non-satisfied with the pension. It is understandable that this general index of satisfaction will predict higher indexes of satisfaction with more particular aspects of life.

For assessment of love was selected the Sternberg's 45-item measure (Sternberg, 1986; Sternberg, 1997), that we have adapted seven 
years before in Latvian and Russian language (Breslavs, 2007; Breslavs \& Tyumeneva, 2008, a). This measure has good psychometric qualities (Breslavs, 2007; Breslavs \& Tyumeneva, 2008, a), and three-factor model, and its basis is shared by other researchers of love (Aron \& Westbay, 1996; Shaver, Hazan, Bradshaw, 1988). This three-factor model was used for beginning of our study on hate as well (Breslav, 2004; Sternberg, 2005).Participants. In Latvia and Russia more than thousand participants completed four questionnaires, but our primary analysis includes Latvian data only'. More than 700 people from two generations filled four questionnaires and 659 were accepted in general statistical analysis of all variables. In the descriptive statistical analysis data of 15 bilingual participants were eliminated. The younger generation (18-25) was represented by 317 participants - 174 female and 143 male, 154 Latvian-speaking and 163 Russian-speaking. The older generation (42-50) was represented by 327 participants - 223 female and 104 male, 155 Latvian-speaking and 172 Russian-speaking.

\section{Results}

Table 1 shows the significant differences in two generations on life satisfaction $(\mathrm{z}=3.29$, $\mathrm{p}=.001)$ general aggression $(\mathrm{z}=3.74, \mathrm{p}=.0002)$ and physical aggression $(\mathrm{z}=3.28, \mathrm{p}=.001)$, anger $(\mathrm{z}=3.11, \mathrm{p}=.0018)$, and love-passion $(\mathrm{z}=2.38$, $\mathrm{p}=.017)$. The differences of generations on other variables are not significant.

\section{Discussion}

Preliminary results of the study showed significant differences in the generations' variables in satisfaction with life, in love-passion, in general aggression variable and in physical aggression and anger. All these variables are higher in the young adult sample. Some of these data can be predicted on the basis of previous studies.

Some works show that aggression in a young adult is higher than in later adulthood using direct measures (Loeber, Hay, 1997) or through decrease of impulsivity linked with all types of aggression (Bailey, Ostrov, 2008). We have data on the dramatic increase of passion as the component of love from adolescence (16-18) to first adulthood (26-28) and the significant decrease for older adults (36-38), but, in the same time, significant decrease of active hate from adolescence to adulthood without differences between adults' groups (Breslavs, 2009). The last data should be taken into account in the interpretation of these data.

\section{Conclusion}

On the basis of these data we can conclude that young post-Soviet generation in Latvia is characterized in comparison with Soviet-educated generation by higher satisfaction with life and by higher love-passion, but at the same time with higher general aggression variable, physical aggression, and anger. These results showed too

Table 1. Comparison of two generations on life satisfaction, aggression, love and hate in Latvia (MannWhitney)

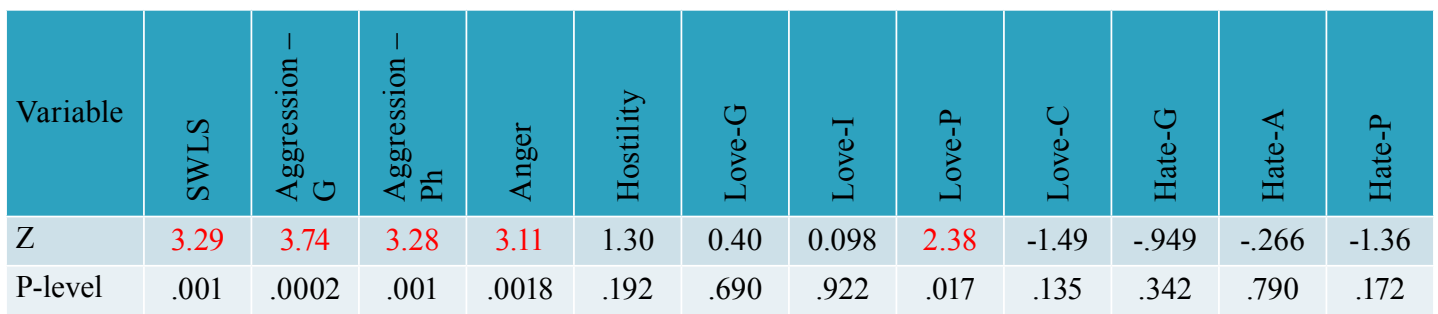


that there are no significant differences in hate between generations, but significant differences in aggression, satisfaction and love-passion could be explained by age development only, indirectly linked to social-political and social-economic changes in societal life. In this sense our data cannot be interpreted to indicate the decrease of psychological security in post-Soviet Latvia. It will be useful to compare these data with the data in different regions of Russia.

\footnotetext{
In Latvia data collected students of the Baltic Psychology and Management University College : Gaevskaja, Malceva, Shamaiko, Korabo, Lekarevich, Urbanovich, Vladimirova, Kartasheva, Krugalauza, Stuka, Silantjeva, Dukate, Sorokin, Gudermane, Aslanjan, Apalja, Cherkovskaja, Jakovleva, Ananich, Skobeleva, Kuznecova, Voevodin, Zhevnova, Povarenkova, Grechnaja, Broks, Koshelev, Usmanova, Safiulin, Zharova.
}

\section{References}

1. Allik, J. \& Realo, A. (1996). On the Relationship between Personality and Totalitarian Regimes: A Critique of Western Stereotypes. Baltic studies, 27, 331-340.

2. Anestis, M. D.; Anestis, J. C.; Selby, E.; Joiner, T. E. (2009). Anger rumination across forms of aggression. Personality \& Individual Differences, Vol. 46 (2), 192-196.

3. Aron, A. \& Westbay, L. (1996). Dimensions of the Prototype of Love. Journal of Personality \& Social Psychology, 70 (3), 535-551.

4. Baron, R., Richardson, D. (1994) Human Aggression. New York: Plenum

5. Bar-Tal, D. (2002). Collective memory of physical violence: Its contributions to the culture of violence. In G. Salomon \& B. Nevo (Eds.), Peace education: The concept, principles and practice around the world (pp.27-36). Mahwah, NJ: Erlbaum.

6. Berkowitz, L (1993). Aggression: Its Causes, Consequences and Control. Boston, Ma: McGraw Hill.

7. Breslav, G. (1994). Vygotsky's concept of the "Social situation of development": Current perspective. Poster presented at 13th Biennial Meetings of ISSBD. Amsterdam, June, 28-July, 2.

8. Breslavs, G. (2007). Personality assessment. Lectures' course in Power Point, Riga: SPPA.

9. Breslav, G. Nenavist' kak predmet psikhologicheskogo issledovaniia [Hatred as an Object of Psychological Research]. Voprosy psikhologii [Issues of Psychology], 2011, No. 2, 138-148.

10. Breslavs, G. (2009). Are adults' love and hate more advanced? The paper presented at the XIVth European Conference on Developmental Psychology, Vilnius, August 17-23, 2009.

11. Breslav, G. Psikhologiia emotsii [Psychology of Emotions], revised and enlarged edition. Moscow: Smysl. 2014.

12. Breslav, G. Psikhologiia emotsii [Psychology of Emotions]. Moscow: Smysl-Akademiia. 2004.

13. Breslavs, G, Ābele, U., Derjabo, L., Pišinska, I. \& Roze, J. (2008). Vai mēs esam iecietīgi ? Sabiedrības etniskās iecietības monitoringa metodikas izveide. Rīga, „Salus”.

14. Breslavs, G. \& Tyumeneva, J. (2008, a). Development of the Russian version of Sternberg's Love scale. The paper presented at the $14^{\text {th }}$ European conference on Personality, Tartu, July, 16-20, 2008.

15. Breslavs, G. \& Tyumeneva, J. (2008, b). Is Hate an opposite to Love? The paper presented at the $14^{\text {th }}$ European conference on Personality, Tartu, July 16-20.

16. Breslavs, G. \& Tyumeneva, J. (2008). Development of the Russian version of Sternberg's Love scale. The paper presented at the $14^{\text {th }}$ European conference on Personality, Tartu, July, 16-20. 
17. Burris, C. E. \& Rempel, J.K. (2008). Value Subtracted: A Conceptual Approach to Devaluation and Hate. The paper presented at the $14^{\text {th }}$ European conference on Personality, Tartu, July 16-20.

18. Burt, S. A., Mikolajewski, A. J. \& Larson, C. L. (2009). Do aggression and rule-breaking have different interpersonal correlates? A study of antisocial behavior subtypes, negative affect, and hostile perceptions of others. Aggressive Behavior, Vol. 35 (6), 453-461.

19. Bushman, B. J., \& Anderson, C. A. (2001). Is it time to pull the plug on the hostile versus instrumental aggression dichotomy? Psychological Review, 108, 273-279.

20. Buss, A. H., \& Perry, M. (1992). The Aggression Questionnaire. Journal of Personality and Social Psychology, 63, 452-459.

21. Cheng, W., Ickes, W., Kenworthy, J. B. (2013). The phenomenon of hate crimes in the United States. Journal of Applied Social Psychology. Vol. 43 (4), 761-794.

22. Diener, E. (1984). Subjective well-being. Psychological Bulletin, 95, 542-75.

23. Diener, E. (2006). Guidelines for national indicators of subjective well-being and ill-being. Journal of Happiness Studies, 7, 397-404.

24. Diener, E., \& Diener, M. (1995). Cross-cultural correlates of life satisfaction and self-esteem. Journal of Personality and Social Psychology, 68, 653-663.

25. Diener, E., Emmons, R. A., Larsen, R. J. and Sharon G. (1985). The Satisfaction With Life Scale. Journal of Personality Assessment, Vol.49 (1), 71-75.

26. Dodge K.A. (1991). The structure and function of proactive and reactive aggression. In: D.J Pepler, K.H. Rubin, (eds.), The development and treatment of childhood aggression (pp. 201-218). Lawrence Erlbaum, Hillsdale.

27. Dollard, J., Doob, L.W., Miller, N.E., Mowrer, O.H. \& Sears, R.T. (1939). Frustration and Aggression. New Haven:Yale University Press.

28. Draguns, J.G. (1999). Homo sovieticus or homines postsovietici? Lithuanian Papers, 13, $18-23$.

29. Ellis, B. J., Malamuth, N. M. (2000). Love and Anger in Romantic Relationships: A Discrete Systems Model. Journal of Personality, Vol. 68 (3), 525-557.

30. Enikolopov, S.N., Meshkov, N.V. Predubezhdennost'v kontekste svoistv lichnosti [Prejudice in the Context of Personality Traits]//Psikhologicheskii zhurnal [Psychological Journal], 2010, No. 4, P. 35-46.

31. Enikolopov, S.N., Tsibul'ski, N.P. Psikhometricheskii analiz russkoiazychnoi versii Oprosnika diagnostiki agressii A. Bassa i M. Perri [Psychometric Analysis of the Russian Version of the Questionnaire of Aggression Diagnostics of A. Bass and M. Perry] // Psikhologicheskii zhurnal [Psychological Journal]. - 2007. - N. 1. - P. 115-124.

32. Fredrickson, B.L., Mancuso, R.A., Branigan, C., \& Tugade, M.M. (2000). The Undoing Effect of Positive Emotions. Motivation and Emotion, v.24 (4), 237-258.

33. Fromm, E. (1956). The Art of Loving.

34. Gudkov, L.D., Dubin, B.V., Zorkaia, N.A. (2008). Postsovetskiy chelovek i grazhdanskoye obshchestvo [The Post-Soviet People and Civil Society]. Moscow: Moskovskaia shkola politicheskikh issledovanii [The Moscow School of Political Studies].

35. Gulens, V. (1995). Distortions in Personality Development in Individuals Emerging from a Long-term Totalitarian Regime. Baltic studies, 26, 267-284. 
36. Hood, R. W. Jr., Spilka, B., Hunsberger, B., \& Gorsuch, R. (1996). The psychology of religion: An empirical approach. New York: Guilford.

37. Kim, J. \& Hatfield, E. (2004). Love Types and Subjective Well-Being: A Cross-Cultural Study. Social Behavior \& Personality: An International Journal, 2004, Vol. 32 Issue 2, 173-182.

38. Klein, M. (1986). The selected Melanie Klein. J.Mitchell (Ed.). London: Penguin Books.

39. Knapp, M.L. \& Vangelisti, A. (1992). Interpersonal Communication and Human Relationships. $2^{\text {nd }}$ ed. Boston: Allyn \& Bacon.

40. Leary, M.R., Twenge, T.M. \& Quinlivan, E. (2006). Interpersonal rejection as a determinant of anger and aggression. Personality and Social Psychology Review, 10(2):111-32.

41. Levada, Iu. Pokoleniia 20 veka: vozmozhnosti issledovaniia [Generations of the Twentieth Century: the Possibilities of Research]// Ottsy $i$ deti: pokolencheskii analiz sovremennoy Rossii. [Fathers and Sons: Generational Analysis of Modern Russia] - Moscow: NLO, 2005.

42. Lawrence, F. M. Punishing hate: Bias crimes under American law. Cambridge, MA: Harvard University Press. 1999.

43. Lickel, B., Miller, N., Stenstrom, D.M.,. Denson, T.F. \& Schmader, T. (2006). Vicarious Retribution: The Role of Collective Blame in Intergroup Aggression. Personality and Social Psychology Review, Vol. 10, (4), 372-390.

44. Loeber, Rolf; Hay, Dale (1997). Key issues in the development of aggression and violence from childhood to early adulthood. Annual Review of Psychology, Vol. 48: 371-410.

45. Lyubomirsky, S., Sheldon, K. M., \& Schkade, D. (2005). Pursuing happiness: The architecture of sustainable change. Review of General Psychology, 9, 111-131.

46. Marcus-Newhall, A., Pedersen, W. C., Carlson, M., Miller, N. (2000). Displaced Aggression Is Alive and Well: A Meta-Analytic Review. Journal of Personality \& Social Psychology, Vol. 78 (4), 670-689.

47. McCauley, C. R. \& Moskalenko, S. (2011). Friction: Radicalization Happens to Them and Us. New York: Oxford University Press.

48. Michener, W. (2012). The Individual Psychology of Group Hate. Journal of Hate Studies. Vol. $10(1), 15-48$.

49. Murray, S. L., Holmes, J. G. \& Griffin, D. W.. (1996). The Self-Fulfilling Nature of Positive Illusions in Romantic Relationships: Love is Not Blind, but Prescient. Journal of Personality \& Social Psychology, v. 71 (6), 1155-1181.

50. Nisbett, R. E., \& Cohen, D. (1996). Culture of honor: The psychology of violence in the South. Denver, CO: Westview Press.

51. Oishi, S., Diener, E., Choi, D. W., Kim-Prieto, C., \& Choi, I. (2007). The dynamics of daily events and well-being across cultures: When less is more. Journal of Personality and Social Psychology, 93, 685-698.

52. Pargament, K., I. (1997). The Psychology of Religion and Coping: Theory, Research, and Practice. New York: Guilford.

53. Pavot, W. \& Diener, D. (1993). Review of the Satisfaction With Life Scale.

54. Psychological Assessment, Vol.5 (2), 164-172.

55. Rempel, J. K. \& Burris, Ch. T. (2005). Let me count the ways: An integrative theory of love and hate. Personal Relationships, 12, 297-313. 
56. Ritchey, P. N. \& Fishbein, H. D. (2001). The Lack of an Association Between Adolescent Friends' Prejudices and Stereotypes. Merrill-Palmer Quarterly, Vol. 47 (2), 188-206.

57. Royzman, E. B., McCauley, C., \& Rozin, P. (2005). From Plato to Putnam: four ways to think about hate. In R. Sternberg (ed.), The Psychology of Hate (pp.3-35). Washington, DC: APA.

58. Shaver, Ph., Hazan, C., Bradshaw, D. (1988). Love as Attachment: The Integration of Three Behavioural Systems. In: R.Sternberg \& M.Barnes (Eds.) The Psychology of Love ( pp.68-99). New Haven: Yale University Press.

59. Sternberg, R. J. (1986). A Triangular Theory of Love. Psychological Review, 93 (2), 119-135.

60. Sternberg, R. J. (1997). Construct validation of a triangular love scale. European Journal of Social Psychology , 27(3), 313-335.

61. Sternberg, R. J. (2003). A duplex theory of hate: Development and application to terrorism, massacres, and genocide. Review of General Psychology, 7, 299-328.

62. Sternberg, R. J. (2005). Understanding and combating hate. In R. Sternberg (ed.), The Psychology of Hate (pp.37-49). Washington, DC: APA.

63. Sternberg, R. \& Barnes M. (Eds.) (1988). The Psychology of Love. New Haven: Yale University Press.

64. Sternberg, R. J. \& Sternberg, K. (2008). The Psychology of Hate. Washington, DC: APA.

65. Sternberg, R. J. , \& Weis, K. (Eds.) (2006). The New Psychology of Love. New Haven: Yale University Press.

66. Weis, K. (2006). Explorations of the Duplex Theory of Hate. Berlin: Logos Verlag.

67. Wulff, D. M. (1997). Psychology of religion: Classic and contemporary (2nd ed.). New York: John Wiley.

68. Zorkaia, N. Privatizatsiia i chastnaia sobstvennost'v obshchestvennom mnenii v 1990-2000e gody [Privatization and Private Property in the Public Opinion in the 1990-2000-s]// Otechestvennye zapiski [Notes of the Fatherland], No. 1 (21) 2005, P. 124-134. 


\section{Психологическая безопасность}

\section{у двух поколений в Латвии}

\section{Г. Бреслав}

\section{Балтийский институт психологии и менеджмента} Латвия, 1011, Рига, ул. Бруниниеку, 65

Распад Советского Союза и переход от «развитого соииализма» к рыночной экономике привел к изменениям образа жизни и установок людей. Сделало ли это взаимоотнотения людей более безопасными? Одним из важнейших сочиально-психологических условий этой безопасности является отсутствие межличностной и межгрупповой агрессии, а также ненависти, как правило, стоящей за вспышками этой агрессии. Изменилось ли это условие в жизни поколения, выросшего и получившего образование уже в условиях рыночной экономики? Сопровождается ли это изменениями психических особенностей, препятствующих вспышкам агрессии, 6 частности изменениями в переживании любви и удовлетворенности жизнью? Целью данного исследования было сравнение агрессии, ненависти, любви и удовлетворенности жизнью у поколения, выросшего в Советском Союзе (43-50 лет), и молодого поколения, выростего уже после распада Советского Союза (18-25 лет) в Латвии. Гипотеза о наличии межпоколенческих различий в этих характеристиках подтвердилась частично - были обнаружены различия в склонности к агрессии, в удовлетворенности жизнью и в страстности любви. Однако обнаруженные более высокие показатели этих переменных у молодого поколения могут объясняться не столько более широкими изменениями общественной жизни, сколько специфическими возрастными особенностями.

Ключевые слова: психологическая безопасность, агрессия, ненависть, субъективное благополучие, удовлетворенность жизнью, любовь, враждебность, межпоколенческие различия.

Научная спечиальность: 19.00.00 - психологические науки. 